\title{
Sociální konstrukce systému sociální ochrany: Administrace klientů jako prostor interpretace
}

\author{
The Social Construction of the System of Social Protection: \\ The Administration of the System of Social Protection as a Space \\ for Interpretation
}

\author{
Ivana Šimíková, Jiři Vyhlídal
}

\begin{abstract}
Modern society is increasingly dependent on the functioning of abstract expert systems, which have become institutionalized form of problem solving, often produced by other abstract systems. The present text attempts to identify and describe the conflicts that arise within one of these systems in the context of the emergence of new social risks. Model case and a source of empirical material is the executive level of the social protection system, on which a process of a continuous interaction between frontline workers and clients is going on. This text is focused on the dilemmas to which these workers are faced in their decision-maiking process. Integral part of the administration of this system is a permanent reconciliation diverging perspectives of universality (the system), and individualization (biography of the client).
\end{abstract}

KEY WORDS crisis of representation, individualization, post-industrializmus, new social risks, social construciton, social protection system, universality, welfare, workfare

The true object of analysis, which must be constructed against appearances and against all those who do no more than endorse those appearances, is the social (or more precisely, political) construction of reality as it appears to intuition, and of its journalistic, bureaucratic and political representations, which help to produce effects that are indeed real, beginning with the political world, where they structure discussion, and extending to the world of science.

Pierre Bourdieu

Předkládaný text ${ }^{1}$ se pokouší konfrontovat teoretickou reflexi aktuálních změn, konceptualizovaných pomocí pojmů jako post-industrialismus, welfare, workfare nebo nová sociální rizika, s reflexí každodenního fungování systému hmotné nouze, jako nejzákladnějšího

Sociální studia. Fakulta sociálních studií Masarykovy univerzity, 1/2010. S. 135-156. ISSN 1214-813X. Autoři by rádi vyjádřili své poděkování oběma recenzentům. Jejich rady a doporučení nepochybně zvýšily kvalitu textu, přičemž prrípadné chyby a omyly samozřejmě padají zcela na hlavy autorů. 
systému sociální ochrany obyvatel, jak je zachycena v rozhovorech s liniovými pracovnicemi ${ }^{2}$ tohoto systému. Cílem textu je ilustrovat na konkrétních výpovědích liniových pracovnic situace, kdy řešení konkrétních problémů, se kterými klienti přicházejí, nabývá povahy systémových dilemat.

Toho lze, dle našeho názoru, dosáhnout tak, že částečně opustíme tradiční strukturu statě, kdy po úvodu následuje sevřené představení teoretických východisek, popis výsledků a z nich vyplývající závěry. Jisté napětí a dilematičnost procesu administrace klientů v rámci českého ${ }^{3}$ systému sociální ochrany, které jsou ústředními tématy statě, jsou nejlépe patrné právě v okamžiku, kdy budou v bezprostředním kontrastu prezentovány reflexe vědecká (ve smyslu textů produkovaných vědci) a reflexe empirická (v tomto případě výpovědi liniových pracovnic). $Z$ důvodu ne zcela obvyklé struktury prezentovaného textu, pro snazší orientaci čtenáře, jsou použity tři typy písma. Standardní font je použit pro text, který má ve výše uvedeném smyslu teoretickou povahu. Zmenšeným fontem jsou vytištěny citace z rozhovorů, reprezentující empirickou reflexi. Citace jsou doprovázeny pasážemi vysázenými kurzívou, které mají za cíl je ilustrovat, doplňovat či komentovat. V tomto smyslu tyto texty nepatří ani do jedné z výše uvedených kategorií, a tvoří tedy kategorii vlastní.

Citace uváděné $\mathrm{v}$ textu pochází z rozhovorů s 25 liniovými pracovnicemi systému hmotné nouze, prováděných v polovině roku $2008 .{ }^{4}$ Empirická data nebyla shromážděna pro účely tohoto textu, ale pro vyhodnocení změn přechodu systému sociální potřebnosti na systém hmotné nouze, ${ }^{5}$ který nabyl účinnosti od 1 . ledna 2007. Reflexe této změny pohledem expertek, které $\mathrm{v}$ přenesené působnosti provádějí výkon státní správy $\mathrm{v}$ této oblasti, byla významnou součástí hodnocení zmíněného přechodu.

Máme za to, že nejen tvrdá data v podobě statistik zohledňujících počty klientů a množství vyplacených dávek ze systému hmotné nouze, ale také výpovědi administrátorek potvrzují rozsah ani ne tak současného, jako spíše potenciálního budoucího problému. V textu se snažíme nahlédnout, jak spolu souvisí a $\mathrm{k}$ jakým př́padným důsledkům mohou vést krize reprezentace paralelně s požadavky na univerzalitu systému sociální ochrany a responsibilizaci klientů. A to primárně z hlediska liniových pracovnic, které tato dilemata nejen vnímají, ale musí je současně i řešit.

\section{Nová rizika a post-industrialismus}

Rizika, která přišla s průmyslovou revolucí, jako riziko ztráty zaměstnání, riziko pracovního úrazu nebo nemoci, tedy situace vedoucí ke ztrátě př́imu, se sama o sobě nemění.

2 Sousloví liniové pracovnice v tomto textu označuje tu vrstvu byrokratického aparátu, která je v každodenním face-to-face kontaktu s občany-klienty.

3 A ne nutně jen českého. Problémy mají pravděpodobně univerzální povahu, protože i analogické systémy $\mathrm{v}$ jiných (evropských) zemích jsou budovány na podobných principech.

4 Rozhovory byly vedeny na jedenácti obecních úr̆adech v České republice, které byly vybrány tak, aby zahrnovaly oblasti s vysokou, průměrnou i nízkou nezaměstnaností a aby v tomto výběru byly zastoupeny i různé velikostní typy správních obvodů.

5 Změna v označení uvedených systémů reflektuje paradigmatickou proměnu záchranné sociální sítě, jejíž pozice, tedy poslední instance v systému sociální ochrany, však zůstává zachována. 
Koncept nových sociálních rizik zohledňuje $\mathrm{v}$ prvé řadě skutečnost, že se mění, především pod silným ekonomickým tlakem, populace, která je definována jako riziková. Ve věku starých sociálních rizik (tento pojem používá např́iklad Taylor-Gooby [2004b]) tvořili nositelé rizik relativně homogenní skupinu, která byla z tohoto pohledu dobře identifikovatelná (proto je problém krize reprezentace ${ }^{6} \mathrm{v}$ dnešních rozměrech zkušeností relativně novou), a tato rizika bylo možné zvládat prostřednictvím institucí sociálního státu založených na různých formách solidarity (zdravých s nemocnými, pracujících s nezaměstnanými, solidaritě mezigenerační atd.). Série změn $\mathrm{v}$ organizaci produkce, která bývá označována jako přechod od společnosti industriální ke společnosti post-industriální, nebo od fordismu k post-fordismu apod., má např́iklad za následek, že nositeli zvýšeného rizika (nejen) nezaměstnanosti se v důsledku flexibilizace pracovního trhu stávají kategorie zaměstnanců, které byly v nedávné minulosti vzhledem ke své kvalifikaci, svým schopnostem a dovednostem před tímto rizikem vcelku spolehlivě chráněny. $Z$ tohoto důvodu je skupina osob zasahovaná novými sociálními riziky značně heterogenní.

Ale to není jediný důsledek změn generovaných ekonomickým subsystémem. Celý soubor změn $\mathrm{v}$ tomto subsystému produkuje změny také $\mathrm{v}$ povaze, preferencích a cílech politik sociálního státu. Bob Jessop je interpretuje jako přechod od keynesiánského národního welfare státu (KWNS) k schumpeteriánskému postnacionálnímu workfare režimu (SWPR; viz Jessop 1996, 2000, 2002). „První změnou je přechod od keynesiánských cílů a modů intervence k schumpeteriánským; druhou je přechod od reprodukce pracovní síly založené na welfare $\mathrm{k}$ reprodukci založené na workfare; třetí je přechod od národního k post-národnímu rámci ukotvení politik; a čtvrtou je přechod od primární role státu při kompenzaci tržních selhání k důrazu na sít'ové, na partnerství založené, ekonomické, politické a sociální mechanismy vládnutí (governance)“(Jessop 2000: 18).

Sociální státy industriální éry zvládaly rizika primárně prostřednictvím horizontálních transferů, pokrývajících skrze mezigenerační solidaritu standardní situace v životním cyklu (péče o děti, penze) a prostřednictvím pojišt'ovacích systémů rizika spojená s dominujícím (industriálním) způsobem produkce (nemoc, trvalejší zdravotní omezení, nezaměstnanost). Vertikální transfery, určené primárně chudým minoritám, tvořily jen relativně malou část všech výdajů sociálního státu (Taylor-Gooby 2004a). Převaha horizontálních transferů výrazně definovala také logiku fungování byrokracie s touto distribucí spojené. V rámci pojištovacích systémů, stejně jako $v$ př́padě programů založených na významných mezigeneračních transferech, vznikaly v daleko menší míře než u vertikálních transferů pochybnosti ohledně

6 Přestože se $\mathrm{k}$ problému krize reprezentace ještě podrobněji vrátíme, $\mathrm{v}$ tuto chvíli bychom pro vyjasnění významu, ve kterém jej používáme, uvedli alespoň koncept Zdeňka Konopáska (1998: 20-21): „Donedávna docela úspěšné a obecně užívané pojmy, kategorie či klasifikace - stejně jako společenské instituce, sociální technologie nebo vědecké teorie na těchto klasifikacích a konceptech vybudované - nám dnes připadají chatrné a deficitní. Jejich referencialita, tedy přímý zastupitelský vztah k tomu, co mají reprezentovat, je principiálně zpochybněna. Někdejší ostré kontury reality se rozmazávají. Dříve jasně definovaní a zcela samozřejmí aktéri jsou nyní objevováni v překvapivých podobách a aliancích [...] sociální zabezpečení je podle mne v nesnázích, protože čelí již zmíněné krizi reprezentace. Přestává být jasné, co vlastně po sociálním zabezpečení chceme a jakým způsobem lze naše úmysly a představy do neosobní logiky dávkových systémů vtělit.“ 
oprávněnosti nároků či jejich výše. Sociální systémy nevykazovaly v takovém rozsahu známky krize reprezentace, mimo jiné i proto, že pravá ruka státu (Bourdieu 1998a, 2003), v souladu s keynesiánskou teorií, prostřrednictvím investic státu podporovala zaměstnanost také aktivní tvorbou pracovních míst. Systém sociálního zabezpečení se v té době zřejmě nejvíce přibližoval ideálu, jak jej vidí např́íklad Konopásek (1998: 123-124), tedy aparátu zbaveného možnosti či povinnosti skutečně rozhodovat o oprávněnosti jednotlivých nároků, který namísto toho na základě jasných pravidel pouze přiřazuje jednotlivé př́pady k pevně stanoveným kategoriím definujícím nárok na službu či dávku.

Přechod k post-industrialismu je charakterizován především ústupem od fordistického typu organizace výroby a s ním spojeným modelem celoživotního zaměstnání, růstem sektoru služeb $^{7}$ a např́klad také změnami $\mathrm{v}$ genderové dělbě práce. Jako důsledek tohoto přechodu, doprovázeného také demografickým přechodem, nevznikají jen nová rizika, ale s jistým zpožděním i technologie jejich zvládání. Nová rizika, na rozdíl od starých rizik, jsou zvládána především prostřednictvím vertikálních transferů, což s sebou přináší i nutnost posuzování oprávněnosti nároků. Tato zásadní změna v technologii zvládání sociálních rizik je doprovázena ještě další významnou změnou: poskytování sociálních služeb potřebným je nahrazováno poskytováním peněžních dávek. Jak tvrdí Bourdieu (Bourdieu a kol. 1999: 184), „,naprosto v souladu s neoliberální vizí př́ímá pomoc ,redukuje solidaritu na pouhé přerozdělování finančních částek' a má za cíl výhradně usnadnění konzumu (případně podnícení k většímu konzumu), bez snahy tento konzum usměrňovat nebo strukturovat. Což znamená, že se přesouváme od vládní politiky zaměrující se na samotnou strukturu distribuce k politice, která má za cíl jen korigovat efekty nerovné distribuce zdrojů ekonomického a kulturního kapitálu.“ S rostoucí nejistotou na trhu práce a postupným vylučováním z pojistných systémů bude pro nejchudší část populace hrát př́ijem ze systému hmotné nouze stále větší roli. Jinými slovy, tito lidé budou ve stále větší míře záviset na schopnosti a ochotě administrátorů ohodnotit jejich nárok jako oprávněný.

Jak hluboká je celková proměna systému, a nyní již nehovoříme pouze o systému sociální ochrany, si uvědomíme, postavíme-li proti sobě dva jiné významné trendy. Na jedné straně dochází $\mathrm{k}$ individualizaci sociálních rizik, se všemi důsledky pro jednotlivce na úrovni ekonomické, sociální i hodnotové. To je patrné především ze snahy omezovat roli kolektivních (veřejných) institucí při pojišstování proti sociálním rizikům (např́klad různé formy privátního připojištění výloh spojených $\mathrm{s}$ dlouhodobým léčením) nebo v situacích, které nejsou rizikem, ale přirozeným důsledkem životního cyklu (změny v systému důchodového pojištění). Role

\footnotetext{
V souvislosti s růstem podílu osob zaměstnaných v sektoru služeb se hovořilo o tzv. Baumolově chorobě jako dalším potenciálním ohrožení zdrojů sociálního státu. Americký ekonom William J. Baumol již v šedesátých letech argumentoval, že přesun zdrojů do sektoru s pomalým růstem produktivity, jakým jsou právě služby, zpomalí růst agregované produktivity (Pierson 2001). Tento argument byl však založen na předpokladu, že stagnující sektor generuje finální produkt. Oulton (2001) ukázal, že produkuje-li tento sektor, jak tomu u služeb často bývá, nikoli finální produkt, ale pouze meziprodukt, tento argument neplatí: „I v př́padě přesunu zdrojů do oblastí jako finanční a obchodní služby, jejichž produktivita roste pomalu, agregovaná míra růstu nemusí nutně klesat... V rozporu se stagnacionistickou argumentací tak může přesun zdrojů do sektoru služeb podporovat růst produktivity“ (Oulton 2001: 626).
} 
kolektivních institucí jako základních prvků sociálního státu je stále více zpochybňována a jednotlivci jsou nuceni obracet se v rostoucím počtu situací na trh. Na druhé straně, jak konstatují Boltanski a Chiapello (2007), dochází stále častěji k socializaci nákladů spojených s fungováním trhu. Jinými slovy, veřejné rozpočty nejrůznějšími formami dotují, at' již př́ímo, či nepř́mo, fungování soukromých nebo polosoukromých firem. Jako př́klad autoři uvádějí, že „,podpora zaměstnávání vybraných skupin občanů (absolventů, dlouhodobě nezaměstnaných nebo osob bez kvalifikace) se stala běžně přijímanou praxí“ (Boltanski a Chiapello 2007: 252). ${ }^{8}$

\section{Systém správy a krize reprezentace}

Jedním z největších a možná i nejpřísněji střežených tajemství byrokracie je její schopnost znovu a znovu unikat paralýze způsobené tím, že by se striktně rídila pravidly, která mají regulovat její vlastní činnost. Zdá se, že právě tato trvalá hrozba paralýzy „otevírá prostor pro manévrování, iniciativu a svobodu, který může být využit těmi, kdo odmítnutím byrokratické rutiny a pravidel zachraňují byrokracii před důsledky jejího vlastního jednání“ (Bourdieu a kol. 1999: 191). Tento text je do značné míry věnován právě uvedenému fenoménu, i když o něm budeme referovat povětšinou nepřímo, protože naši pozornost soustředíme především na předpoklady, které určitým způsobem jednání byrokratického aparátu orientují, a pak na důsledky, ke kterým tato řešení vedou.

Dřive než se začneme věnovat samotnému procesu administrace pomoci v hmotné nouzi, je nezbytné se alespoň stručně věnovat pozici, ve které se nachází specifická vrstva byrokracie, liniových pracovníků pomoci $\mathrm{v}$ hmotné nouzi. Uvedení pracovníci patř́ mezi typické představitele té části státní byrokracie, kterou Bourdieu označuje jako levou ruku státu (Bourdieu 1998a, 2003). Jsou to především zaměstnankyně a zaměstnanci státních a veřejných institucí v oblasti školství, zdravotnictví a sociálních věcí, kteří tvoří „levou ruku státu, soubor zaměstnanců takzvaných utrácejících ministerstev, kteří uvnitř státní administrativy představují stopu minulých sociálních zápasư“ (Bourdieu 1998a: 2). Právě tito lidé zosobňují to, co je běžně nazýváno sociálním státem. Ale nejsou to jen oni. Patř́i sem i zaměstnanci neziskových organizací a soukromých firem, které se angažují v sociální oblasti, školství, zdravotnictví apod.

Jak konstatuje řada autorů (viz např́íklad Horák a Horáková 2009; McDonald a Marston 2005; Rosenthal a Peccei 2006, 2007), nedílnou součástí práce úzké vrstvy byrokratické struktury ocitající se v dennodenním kontaktu s klienty, liniových pracovnic systému pomoci v hmotné nouzi, je také řešení dilemat vyplývajících z aplikace obecných pravidel, definujících způsoby nakládaní s osobami v hmotné nouzi, na konkrétní případy. Narážíme zde nutně na problémy definované jako krize reprezentace a usmiřování hledisek univerzality a individualizace, které musí být řešeny v rámci každodenního fungování. Př́tomnost těchto dilemat

8 A našli bychom jistě více př́kladů. Jako určitou formu dotace soukromého podnikání můžeme vnímat i prostý fakt nutnosti přijmout nabízené zaměstnání každým, kdo žádá o dávky hmotné nouze. Takto vytvářená „nabídka“ pracovní síly nucené akceptovat i velmi nevýhodné podmínky je také formou snižování nákladů na pracovní sílu. Nakonec i trend v omezování rozsahu plnění ze systémů veřejného pojištění, at' již se jedná o penze, zdravotní pojištění či nezaměstnanost, je vlastně formou vytváření prostoru pro komerční formy pojištění. 
není charakteristická jen pro systém hmotné nouze, je vlastně součástí jakéhokoli úředního rozhodnutí, které vždy z definice současně zákon sleduje a zákon vynucuje (byrokracie je držitelem monopolu na legitimní symbolické násilí), ale každé rozhodnutí zároveň zahrnuje i zájmy, postoje a hodnoty jak úředníků samotných, tak třetích osob. Jak uvádí Bourdieu, „libovolná byrokratická organizace... není pouhým nástrojem sledujícím kvasi-mechanickou logiku disciplíny, schopným proměnit jakoukoli akci v pouhou exekuci - tato krajní mez zůstává nedosažitelná, a to i v takzvaných ,totálních institucích “ (Bourdieu 2005: 130, zvýrazněno v originále).

Hladké fungování nejen byrokratického, ale jakéhokoliv systému závisí na naší schopnosti definovat vzájemný vztah mezi podmínkami a situacemi, které mohou nastat, a odpovídajícími reakcemi systému. Při administraci systémů sociálního státu jde jednak o to, aby byly definovány situace, za kterých se občané mění v klienty, prŕijemce odpovídající formy pomoci. A také o to, jak tvrdí Konopásek, ,aby institucionální definice chudých a jinak sociálně ohrožených odpovídaly tomu, jak potenciálně chudí a jinak sociálně ohrožení sami sebe vidí a jak vidí poslání sociálního zabezpečení“ (Konopásek 1998: 103).

V obou zmíněných ohledech však systémy sociálního státu narážejí na obtíže, jejichž řešení se vymyká standardním administrativním postupům. Vznik rozporů a dilemat, mající rozhodně potenciál paralyzovat byrokratický systém, není primárně důsledkem náhlé neschopnosti systému zvládat rizika, která dřive více či méně spolehlivě zvládal. Vznik těchto rozporů souvisí spíše s proměnou ani ne tak charakteru jako spíše kontextu těchto rizik. Kategorie nových sociálních rizik (viz např́klad Bonoli 2007; Cerami 2008; Manning a Shaw 2000; Taylor-Gooby 2004b,c) je běžně konceptualizována právě jako reflexe faktu, že existující byrokratické systémy vybudované ke zvládání sociálních rizik a problémů (nyní vlastně již starých sociálních rizik) přestávají plnit svou funkci a musí být re-konstruovány.

Koncept krize reprezentace, který je implicitně přítomen ve všech definicích a intepretacích rozdílů mezi starými a novými sociálními riziky, v sobě především skrývá zásadní problém epistemologický. Podle Konopáska (1998), jak vyplývá z již dříve citované pasáže, se krize reprezentace projevuje v prvé řadě erozí významů obecně užívaných pojmů, kategorií či klasifikací. Ale již samy pojmy, prostřednictvím kterých problém krize reprezentace postihujeme, jsou tímto problémem stiženy. Je to patrné především z toho, jak roste tendence vymaňovat pojmy se silným naturalizačním ${ }^{9}$ efektem z jejich původního kontextu. Namísto o sociálních rizicích tak hovoříme o nových sociálních rizicích, namísto chudoby o problému nové chudoby nebo o sociálním vyloučení.

Jedním ze základních výrazů krize reprezentace je nekompatibilnost zákonných ustanovení se situacemi, na jejichž řešení mají být nastavena. Ve věku nových sociálních rizik, kterým musí systémy sociálního zabezpečení spravované jednotlivými sociálními státy čelit, se tato vzájemná nekompatibilita ještě prohlubuje. Komplementární systémy (pojišt'ovací schémata, dávková schémata adresně podporující určité skupiny obyvatel anebo reagující na situace, ve kterých se lidé ocitají [v českých podmínkách např́klad systém státní sociální

9 Naturalizace představuje proces, ve kterém dochází k proměně historicky vzniklých a historicky omezených sociálních konstruktů v entity, které vnímáme jako přirozené a neměnné, zbavené vlastní historie (viz např́klad Bourdieu a Wacquant 1992, Konopásek 1998). 
podpory] apod.) zpř́sňují podmínky, za nichž vzniká nárok na jejich výplatu. Snižuje se výše podpor, zkracuje se podpůrčí doba, prodlužuje se pojišt'ovací období a tím i oddaluje nárok, ale také se čím dál větší počet dávek prríjmově testuje (u nás např́íklad dříve př́ijmově netestovaný př́ídavek na dítě je $\mathrm{v}$ současnosti odstupňován podle násobků životního minima, které představuje př́ijem rodiny) apod. To mimo jiné způsobuje, že se čím dál větší počet lidí stává závislým na systému, který je v rámci sociální sítě koncipován jako poslední instance (po kterém následuje již jen systém trestní [ $\mathrm{k}$ tématu penalizace chudoby a sociálního vyloučení viz např́klad Wacquant 2003a, b, 2008]).

$V$ českých podminkách je poslední instancí systém hmotné nouze. Vzhledem k tomu, že jde o formu pomoci, která přicházi na řadu až v okamžiku, kde ostatní (pojištovací, podpưrné) sociálni systémy selhaly, je zde reálné riziko, že se do něj dostanou nejen ti, kdo z nich byli vyloučeni, ale i ti, kteři nadále zůstávaji jejich klienty, ale nenalezli $v$ nich adekvátni ochranu.

Tento proces s sebou nese pro naše téma (minimálně) dva relevantni důsledky. Jednak se do tohoto subsystému dostávaji lidé z velmi ri̊zných di̊vodi̊, s rozdilnými biografiemi, životnimi styly, postoji, ale také potřebami. Typicky jde o invalidni a starobni důchodce, jejichž př́jmy jsou bud'to pod, anebo těsně nad hranici objektivně stanovené př́jmové chudoby, osoby se zdravotními omezeními (které nezakládaji nárok na invalidni di̊chod) anebo ti, jejichž věk či zdravotní postižení nárok na starobní či invalidní di̊chod sice zakládají, kteři však nesplňují podmínku povinné doby pojištěni, osamělé matky s nezaopatřenými dětmi, lidé źijicí alternativním způsobem života, ale také nezaměstnani, kteři ztratili pracovni příjem z di̊vodù, které nemohli ovlivnit.

„Jsou to lidé, kteří ještě nejsou starobní důchodci, ale už mají dost pokročilý věk, nikdo po nich nešáhne, at půjdou kamkoliv. Co jsou to teda? Do které kategorie mají jít? Těch je mně líto.“

„Ty osudy životní nejdou všechny včlenit do zákona, zákon je norma, která je obecná pro společnost té které kultury, a nejde to opravdu všecko konkrétně vychytat."

Mezi jinými autory např́ílad také Chiara Saraceno (2002) konstatuje, že změny v systémech sociální ochrany v řadě evropských zemí sledují podobný trend: dochází k redukci počtu kritérií pro určování oprávněnosti (definice klienta) a tento omezený soubor kritérií je aplikován na všechny žadatele. Především aktuální změny na pracovním trhu však zároveň způsobují nárůst heterogenity př́ijemců sociální pomoci. V praxi pak dochází k tomu, že stále heterogennější skupina žadatelů o sociální (finanční) asistenci ze strany státu je klasifikována podle stále menšího počtu základních kritérí, které v řadě př́ípadů nedokáží zohlednit specifičnost situace toho kterého žadatele.

$V$ podminkách oddělení hmotné nouze se tato souvislost ve změně institucionálních definic nároku na dávku hmotné nouze projevila např́klad v tom, jak mnohé úřady spojily úseky, které byly dřive formálně 
oddělené. V radě př́padi̊ tak byly sloučeny do jediného pracoviště úseky, které se odděleně věnovaly rodinám s dětmi a nezaměstnaným jednotlivcům. Vznikala tak jednotná oddělení hmotné nouze. Již nebyl důvod posuzovat jednotlivé kategorie žadatelů odděleně, když se formální kritéria, a to poměr př́jmů a životnich nákladĩ a aktivita při hledání pracovního uplatnění, stávaji jednotnými pro všechny.

„Právě od toho, co začal platit ten nový zákon, tak jsme to udělali tak, že, původně jsme to měli rozdělené na rodiny s dětmi a na nezaměstnané, takže tři pracovnice dělaly ty zaměstnané, jak jsme jim říkali, ty osoby samostatné, a tři dělaly ty rodiny s dětmi. Pak teda, když začal platit ten zákon, tak už jsme to měli připravené tak, že budou dělat všichni všechno. A mají to opravdu rozdělené jenom podle abecedy, ale rozdělili jsme to tak, že ted' dávky dělají čtyři, to znamená dvě a dvě v každé kanceláři, a dvě pracovnice dělají aktivizační plány.“

Subsystém sociální ochrany, hmotná nouze, tedy nezůstává bez odezvy na probihající ekonomické a společenské změny a i v něm se prosazuje tendence $k$ větš̌i adresnosti či presněji zpřisñováni podmínek nároku a jejich odstupňování. Nárok se podmiňuje účastí v jiných systémech (pojištovacích systémech a systému státní sociálni podpory), zvyšuje se počet dokumentù, které člověk musí doložit stejně jako množství skutečností, které musí prokázat, včetně různých forem aktivit, zejména snahy zvýšit si přjiem vlastním přičiněním, kterou jsou jednotlivé dávky podmiňovány, a uplatňují se rưzné sankce za nedodrženi těchto podminek. Jisté hledisko univerzality, obsažené v minulém systému (sociálni potřebnosti) vázáním nároku na ztrátu príjmu, je nahrazeno principem individualizace (a responsibilizace).

Problematičnost této změny se projevuje mimo jiné tím, že v současnosti velmi adresně nastavený systém s takovou mírou heterogenity př́jemců neumi pracovat. S jistou dávkou zjednodušení lze říci, že jediná dvě kritéria, kterými administrátorky třídí své objekty, je výše jejich př́jmu a schopnost si jej vlastnimi silami zvýšit. Dưvody, kvi̊li kterým je jejich př́jem nedostatečný, nehrají v podstatě žádnou roli. Do systému hmotné nouze jsou tak zahrnuty rĩzné skupiny osob, které se ocitaji na hranici chudoby z naprosto rozdilných di̊vodi̊. Systém však neposkytuje administrátorkám žádný prostor, jak tuto rozlišnost v individuálních biografiích zohledňovat. Po půlročním pobiráni přispěvku na živobytí (jednoho ze tř́ typư dávek hmotné nouze, dalšimi typy jsou pak doplatek na bydlení a mimořádná okamžitá pomoc) jsou napřiklad v rámci novely zákona (účinné od letošního roku) všichni př́ijemci př́spěvku na živobytí konfrontováni s nezbytností přijmout výkon veřejné služby výměnou za dávku ve výši životního minima.

„Já vím, že to pan ministr Nečas myslel velice dobře a že to chtěl omezit, aby lidi byli odpovědní víc za sebe, je to v pořádku, já s tím naprosto souhlasím, jo. Že každej by se měl postarat sám o sebe. Ale oni totiž udělali jasný kategorie. 
Oni udělali: ty musíš pracovat nebo jsi invalida, tak máš invalidní důchod, nebo jsi starobní důchodce. Prostě oni udělali raz-dva-tři-čtyřri. Ale oni jsou lidi, kteří nejsou ani to, ani to."

Dochází k jistému rozporu: čím heterogennější je skupina, která se může ocitnout v situaci hmotné nouze (často v důsledku projevu nových sociálních rizik), tím homogennější podmínky, tedy užší kategorie, pro přiznání určitého typu pomoci jsou nastaveny. Zužování kritérií pro přiznání nároku je možné jen díky tomu, že existuje univerzální kritérium určující nárokovost žadatele. A tím je pracovni aktivita. ${ }^{10} \mathrm{~V}$ takto definovaném systému jsou všechny nároky vázány na pracovní aktivity či aktivity vedoucí k pracovnímu uplatnění; ovšem bez ohledu na to, proč k prrípadnému upadnutí do ne-aktivity (ztrátě př́ijmu) v rámci individuálního př́iběhu došlo.

Na institucionální rovině tak dochází ke zdůrazňování principu osobní zodpovědnosti za svůj životní projekt a k tomu, že se nebere v úvahu, zda je aktuální sociální situace klienta důsledkem nevědomosti, nerozvážného chování, špatných rozhodnutí nebo rozhodnutí třetích osob, které klient nemohl nijak ovlivnit. V systému se tyto důvody, a tedy i konkrétní situace lidí, stávají neviditelnými, nepracuje se s nimi jako s významnými okolnostmi. Výsledkem je, že nejen v České republice, ale i v mnoha jiných zemích dochází ke stírání hranic mezi rozdílnými skupinami př́ijemců, které jsou podrobovány stejným formám př́mého dohledu. „Požadavek na přijetí jakékoliv práce výměnou za dávku - workfare - je ve stále větší míře spojován nejenom se sociální pomocí, ale také s ostatními dávkami sociálního zabezpečení“ (Saraceno 2002: 237). Zamlčeným, ovšem ne vždy splněným předpokladem je to, že práce je těmto osobám skutečně dostupná.

\section{Welfare a workfare}

Politiky zvládání nových rizik, jak uvádí Taylor-Gooby (2004a: 10), „mají často za cíl pomoci více lidem tak, aby si pomohli sami prostřednictvím placené práce“. Zatímco tedy EspingAndersen (1990) na počátku devadesátých let minulého století sociální stát spojoval s dekomodifikací, přechod k post-industrialismu a vznik nových rizik ve stále větší míře vede k tomu, že sociální stát je nově definován jako prostor administrativní rekomodifikace (Offe 1984). Holden (2003: 313) při analýze implementace politik New Labour ve Velké Británii dochází k závěru, že tyto politiky ,nejsou založeny ani na prosté dekomodifikaci, ani na 'rekomodifikaci' dosahované prostřednictvím ústupu státu, ale na využití intervencí ze strany sociálního státu pro podporu a zlepšení trhu“. Dominující formou státních intervencí ve prospěch trhu je aktivizace (administrativní rekomodifikace) osob v ekonomicky aktivním věku, kteří jsou aktuálně mimo trh práce. Welfare státy druhé poloviny 20 . století se ve 21 . století mění na workfare státy.

10 Jde o pracovní aktivitu v širším smyslu slova, tedy nejen o výkon konkrétního zaměstnání či veřejné služby, ale také o aktivní hledání nového zaměstnání od okamžiku, kdy se člověk stane nezaměstnaným. 
Principy sociálních politik s rysy workfare se začinají prosazovat $i$ v našich podmínkách a jsou patrné právě v prechodu od systému sociální potřebnosti (viz celá související legislativa účinná do 31. 12. 2006) k systému hmotné nouze (viz celá související legislativa účinná od 1. 1. 2007). ${ }^{11}$ Systém hmotné nouze je postaven na principech, které jsou popsány $v$ dưvodových zprávách $k$ novým zákonům (zákonu o životním a existenčním minimu a zákonu o hmotné nouzi). Vúvodních částech dưvodových zpráv $k$ těmto stěžejním legislativním pramenům systému hmotné nouze (pro oba zákony jsou di̊vodové zprávy takřka totožné), v oddíle Odi̊vodnění hlavnich principů navrhované právní úpravy, je uvedena jako jeden z hlavnich cílu „motivace pro přijetí zaměstnání, a to $i$ v př́padě zaměstnání hưre placeného“ a dalši z principů je deklarován konstatováním, že zákonná úprava ,vychází z principu odpovědnosti jednotlivé osoby za své sociální postaveni' ". ${ }^{12}$

Diskurzivní obrat spojený s přechodem od welfare k workfare (Leonard 1997) je charakteristický potlačením vlivu strukturálních podmínek na šance jednotlivců být v životě úspěšný a začlenit se do společnosti. Základním konceptem se stává responsibilizace. Příčiny selhání jedince, jako v př́padě nezaměstnanosti, již nejsou vnímány jako důsledek strukturálních dysfunkcí, ale jako problém behaviorální (a stále více morální), spojený s odpovědností jedince za svou situaci, za svůj blahobyt a blahobyt své rodiny.

11 Identifikace hlavních změn a zavedení nových institutů, ke kterým došlo v důsledku přijetí nové legislativní úpravy a na základě kterých usuzujeme na přechod systémů, je založena na analýze bývalého a aktuálního zákona o životním minimu, zákona o sociální potřebnosti a zákona o hmotné nouzi, důvodových zpráv k novým zákonům, tiskových zpráv ministerstva a dalších dokumentů. Jde zejména o tyto změny:

- zavedení institutu existenčního minima;

- změna konstrukce životního minima z dvousložkového na jednosložkové a vznik dvou samostatných dávek, příspěvku na živobytí a doplatku na bydlení;

- změna tzv. okruhu společně posuzovaných osob;

- zavedení tzv. aktivizačního plánu, který byl od ledna 2009 nahrazen zavedením povinnosti dobrovolnické či veřejné služby;

- změna způsobu zápočtu př́ijmů (ze zaměstnání, podpory v nezaměstnanosti a při rekvalifikaci a pobírání nemocenských dávek) pro nárok na př́spěvek na živobytí a stanovení jeho výše;

- redukce typů dávek mimořádné okamžité pomoci spojených se striktním vymezením situací a podmínek, za kterých na ně vzniká nárok.

K bližšímu popisu uvedených změn viz Jahoda, Kofroň a Šimíková (2008).

12 Postupy a procesy, jakými sociální zákonodárství konstruuje své klienty, jsou nejzřetelnější v obdobích změny. Takovou změnu popisují McDonald a Marston (2005: 375-376) na př́íkladu konstrukce nezaměstnaných v rámci „liberálních welfare států druhé poloviny 20 . století“ a „rozvinutých liberálních workfare států 21 . století“. V prŕípadě workfare států ekonomická vysvětlení nezaměstnanosti ustupují vysvětlením behaviorálním, a v konečném důsledku morálním. 


\section{Pracovnice tuto zásadní změnu reflektují a popisuji i jeji efekty v souvislosti s bezprostředními reakcemi klientů na ně.}

„Opatření jsou tam dost drastický, bych řekla, hodně drastický, protože já sice vím, že to je pořád směřovaný $\mathrm{k}$ tomu, aby ti lidé si co nejrychleji našli tu práci, a aby nebyli závislí a aby se starali o svoje bydlení sami. Víte, ale ono se tak trochu pořád zapomíná na ty lidi, co jsou někde mezi tím. Nejste to ani vy, ani asi já, ale je spousta lidí, kteří jsou něco mezi, jo?“

„Další, co si myslím, že hodně ovlivnilo počet klientů směrem dolů, byly tak zvané jednorázové pomoci. Současný zákon o pomoci v hmotné nouzi taxativně vymezuje pět situací mimořádných okamžitých hmotných pomocí, takže tam vlastně prostor pro nějaké ty jednorázové dávky, které dřív byly přiznávány, není. Nechci říci, že by dř́v nebyly dávány nějak cíleně nebo bez dobrého úmyslu, ale přeci jenom někdy se zohlednila situace rodin a ty dávky se poskytly. V současné době je to poněkud obtížnější, klienti to vnímají velice nelibě. Ted' tady mívám poměrně často, že si chodí stěžovat vedoucí, a apelují na mě a na mé dobré srdce a já nevím na co, abych tu jednorázovku dala. Takže já všem říkám, že jednorázové dávky neexistují, jsou mimořádné dávky okamžité pomoci, které jsou taxativně vymezeny a týkají se, a ted'ka vyjmenuju těch pět situací životních, a sice to ti klienti nevnímají dobře, ale pro nás je to dobře, protože máme oporu v zákoně.“

\section{Proces zvládání nových sociálních rizik}

Posuzování oprávněnosti či neoprávněnosti se tak stále více propojuje s ochotou participovat bud'to přímo na trhu práce, nebo na veřejně prospěšných pracích. S příchodem workfare politik se tedy významně mění funkce celého systému hmotné nouze. Ze systému vesměs pasivního, jehož primárním účelem byla distribuce služeb a posléze stále častěji dávek, se mění v systém aktivní (respektive aktivizační), mezi jehož úlohy vedle distribuce služeb a dávek patř́ i snaha měnit hodnoty, preference a v konečném důsledku i jednání klientů. To s sebou nese další změnu, která vyplývá z již citovaného Holdenova závěru, a to, že bude těžké naplnit neoliberální představu štíhlého, ale silného a efektivního státu. Naopak se zdá, že nové funkce, které jsou postupně na liniové pracovníky v sociálních službách delegovány, budou vyžadovat, pokud nemají být naplňovány pouze formálně, vyšší míru specializace jednotlivých pracovníků, a v důsledku toho se budou stále častěji objevovat požadavky na kapacitní posílení této vrstvy byrokracie.

Jak konstatují Horák a Horáková (2009: 371), liniové pracovnice se postupně ocitají v situaci, která pro ně není ani komfortní, ani snadno řešitelná: „Na jedné straně se totiž od nich očekává, že budou jednat s klienty jako s jednotlivci. Rostoucí počet uživatelů je ale na straně druhé nutí vymýšlet rutinní aktivity, které umožňují klienty 'zpracovat' v masovém měřítku." V tomto bodě se velmi často odkazuje k nejrůznějším technikám konstrukce nebo sterotypizace klienti̊, jako jedné formě zvládání tohoto dilematu (Rosenthal a Peccei 2006, 2007). Jinou formou, odpovídající určitým vnitřním tendencím byrokracie, je rutinizace a formalizace předepsaných postupů pro jednání s klienty (viz např́iklad Horák a Horáková 2009). Tato vysvětlení, jakkoli mohou v řadě prrípadů reflektovat procesy skutečně probíhající 
na jednotlivých úřadech, pomíjejí změny, které se odehrávají mimo dosah liniových pracovníků, ale které mají významný vliv na jejich každodenní činnost. Transformace welfare ve workfare není reprezentována jen implementací aktivizačních politik, ale také významnou proměnou obecně uznávaných vzorců interpretace a způsobů konstrukce sociálního světa.

Administrátorky neřeši pouze dilemata, která vznikají jako důsledek situací, jež zákon v nějaké formě predvídá, a mohou tedy být rešeny v rámci zákona. Významná dilemata jsou spojena již se samotným posouzením nároku na př́spěvek na živobytí (tedy nároku na klíčovou dávku hmotné nouze), kdy se posuzuje snaha o zvýšení př́jmu, zejména vlastní prací, a ve výkladu této snahy panuje nejistota a arbitrárnost.

„No tak hlavně pochopit i to, co ten zákon po nás chce při posuzování zvyšování toho př́ijmu. Takže dokud jsme vlastně nejeli na poradu na kraj, a takhle jsme si to nesjednotili v rámci všech úřadů, tak to bylo takový docela, že bylo i hodně dotazů na ten kraj, takže to chodily třeba denně e-maily s odpověd’mi na ten dotaz i jiných úřadů, aby se to sjednotilo všude, a vysvětlili jsme si to, co tím vlastně chtěl básník říct.“

„Tazatel/ka: A stává se, že některý ty jiný úřady si stejné věci vysvětlují jinak? Že je třeba jinak uplatňují?

Respondentka: Ve věcech zákona bych řekla, že ani ne. Spíš někde v tom př́stupu trošku jinak."

Vyskytujicí se dilemata jsou tedy mimo jiné di̊sledkem zvyšujici se heterogenity př́jemcü, která není systémově, formou jasně daných kritérii a pravidel posuzování, zohledňována při vyhodnocování nároku na dávku, př́padně její výši. ${ }^{13}$ Napríklad výše príspěvku na živobytí je poměrně striktně stanovena, odvíji se pouze od počtu, pořadi a věku osob ve společně posuzovaném okruhu, posléze je pak navýšena či snižena o bonusy či penalizace v závislosti na prokazované snaze a aktivitě; jakékoliv specifické potreby, s výjimkou dietniho stravování, nejsou zohledňovány.

Pracovnice, nejnižši článek systému hmotné nouze, jsou pak konfrontovány s připadnými diskrepancemi mezi zákonnými nároky a složitostí okolností, připadně potřeb osob, se kterými vyjednávají. Čelí tak protisměrným tlakưm, jednak ze strany požadavků klienti̊, jednak ze strany zákona, který různost požadavků reflektuje jen omezeně, a v neposlední řadě $i$ ze strany organizace, která do procesu aplikace zákona vnáši ekonomické nároky, které jsou s deklarovanými cíli ne vždy slučitelné. Problémem jsou i časové limity, které se zkracují s přibývajícím počtem klientů anebo náročností (nestandardností) př́padi̊. 
„...tak i klesl počet dávek, ale neklesl počet klientů, protože musíme se zabývat a musí prokazovat např́íklad tu snahu každý měsíc, ty aktivity při hledání zaměstnání, tak musí dokládat za všechny ty členy. Takže ono vlastně stejně, jak jsme pečovali předtím o určitý počet klientů, tak je to i v současné době.“

„Ale pokud to má být o sociální práci, tak to prostě je o sociální práci. Ono, než se vyplní s takovým průměrným naším klientem žádost o př́spěvek na živobytí, tak to trvá třeba hodinu a půl, protože ta je velice složitá, myslím si, že i pro vysokoškolsky vzdělaného člověka.“

Klasifikace klientů je vnímaná jako přirozená, nevyhnutelná součást práce liniových pracovníků. Prostřednictvím klasifikací linioví pracovníci často zvládají problémy vyplývající z množství a heterogenity klientů (Mennerick 1974). At’ již jsou tyto klasifikace založeny na profesních typologiích (Mennerick 1974) nebo na individuálních stereotypech (Janebová a Černá 2008), jsou vždy interpretovány jako potenciální zdroj rizik, která je možné zmírňovat profesním vzděláváním pracovníků a důrazem na etické principy, kterými se jejich profese řídí. A jistě by profesní vzdělávání mohlo do značné míry toto riziko eliminovat, pokud by skutečně bylo tak snadné rozlišit profesní typologie a stereotypy na jedné straně a objektivni sociální realitu na straně druhé. Ale co si počít v př́padě, když i ona objektivni sociální realita vzniká, je neustále re-konstruována, na základě obecně sdílených interpretací a klasifikací? Používaná klasifikační schémata pak nevycházejí z profesních typologí liniových pracovníků jako profesionálů v dané oblasti, ale jsou vlastně re-produkcí sdílených klasifikačních schémat, z nichž je sestavena objektivní sociální realita.

Tento sdílený pohled na sociální skutečnost, tato doxa (Bourdieu 1977), vytvář́ základní strukturu světa, ve kterém žijeme, a je základním předpokladem sociální, tedy kolektivně sdílené zkušenosti. „Podstatou symbolického řádu je, že jsou určitému celku aktérů vnuceny poznávací struktury, které za svou trvalost a odolnost vděčí zčásti tomu, že jsou, alespoň zdánlivě, koherentní a systematické a že harmonují s objektivními strukturami sociálního světa“ (Bourdieu 1998b: 89). Pojmy jako nezaméstnanost, chudoba nebo závislost jsou v tomto smyslu konstrukce, za nimiž se skrývá celá sít' (hierarchizovaných) vztahů existujících v dané společnosti. Tyto pojmy tedy ve skutečnosti, jakkoli nám to tak může na první pohled připadat, nepopisují, ale reglementují a v jistém smyslu produkují nezaměstnanost, chudobu nebo závislost.

Konstrukce klienta, jeho vlastností a s nimi spojených očekávání, v systému hmotné nouze nejzřetelněji vyvstává $\mathrm{v}$ konfrontaci se situací, se kterou se nepočítá. $\mathrm{V}$ tomto př́padě je takovou situací vlna masového propuštění jako důsledek uzavírání celých výrobních provozů. Nutno podotknout, že fakt, že se s podobnými situacemi nepočítá, je poněkud paradoxní a možná i iracionální. Celý proces flexibilizace pracovní síly totiž může vést ve svých důsledcích právě k takovým situacím. Tyto situace jsou, stejně jako ekonomická krize, jíž jsou důsledkem, interpretovány jako něco nepředvídatelného, výjimečného a dočasného. 
$V$ metodickém pokynu č. 6/2008 K postupu orgánů pomoci v hmotné nouzi při řě̌ení situace osob, které byly zasaženy utlumením výroby a následnou ztrátou zaméstnání, se osoby, které se takto ocitly bez práce, popisují následovně: „,Jde většinou o osoby, které do té doby dlouhodobě pracovaly, byly plně ekonomicky i sociálně nezávis lé a pracovat nadále ch tějí. Svou situaci vnímají rozjitřeně a považují ji za n e s pravedlivou. “ A pracovníci jsou instruováni, že „Jednání s osobami, které byly takto postiženy, je nezbytné vést vstřicně a citlivě s vědomím specifičnosti situace vzniklé b e z j e j i c h zaviněni “ (zvýrazněno autory).

$V$ těchto a dalšich doporučeních se objevuje do té doby potlačovaný diskurz nezaměstnaných jako obětí strukturálnich potíżi, těch, ke kterým je systém nespravedlivý, ${ }^{14}$ a o to výrazněji vyniká pojetí těch, pro které byl nový systém primárnè vytvořen, jako vinikü, pro které je př́sné posuzování nároků a snižování finanční podpory spravedlivým trestem za neochotu pracovat či lenost a prirozený sklon ke zneuživáni systému.

$V$ podstatě v souladu se závěry autorů zabývajících se sociální konstrukci klientů (Mennerick 1974, Rosenthal a Peccei 2006) je i v systému hmotné nouze nejdůležitějš́m kritériem postoj k práci (který odpovidá reprodukci základního principu pojetí práce jako univerzálni povinnosti, morálního závazku), dále osobní dojem během interakce (příjemnost, př́stupnost), vděčnost či pokora, anebo naopak sklon $k$ agresivitě či tendence ke zneuživání. Tato kritéria se pak pojí s dobře známými kategoriemi tzv. zasloužených (deserving) a nezasloužených (undeserving), s tím, že ta pozitivně hodnocená jsou spojována s první kategorií a naopak. V kategorii zasloužených se typicky objevuji starši lidé, zejména di̊chodci, zvláště pokud mají zdravotni potizze, lidé v ekonomicky aktivním věku se zdravotními omezeními a také osamělé matky s dětmi. Vkategorii opačné pak ti, kteři vyznávají alternativní životní styly, lidé závislí na alkoholu a jiných návykových látkách, bezdomovci a etnické menšiny, zejména Romové. V připadě tzv. deserving se pak v rámci individuálního př́stupu administrátorky uchyluji ke změkčování pravidel, a pokud to možné není, interpretuji to jako selháni skutečné pomoci.

„To jsem tady měla zrovna včera paní s pánem, to byli manželé, starší. Pán pořád pracoval, pak ztratil práci. My tady máme takovej správnej region, že? Tak ztratil práci, šel na úřad práce. Tam teda měl nějakou tu podporu, ta mu skončila. A ted' teda se přišoupal, o dvou berlích v podpaží, že tam má problémy. Měl na tom ortézu. A že teda aspoň půl roku dalšího bude nemocnej. A jeho paní se ptám: ,A vy děláte jako co?’ A ona ř́ká: ,No tady v [název zaměstnavatele].' A já říkám: „Kolik máte ten výdělek?’ A paní, ještě taková hodná, ona ř́ká: ,No dobrý. Já, když máme dobrej měsíc třeba, když se daří, tak já mám třeba aji devět čistýho.' Já si říkám: ,No, tak to máte skutečně hodně, protože tím pádem my vám nedáme ani korunu' [vysloveno ironicky]. Protože oni se do ničeho nevlezou. prostě selhal ve svém snažení se na pracovním trhu uplatnit. 
I když se ten př́ijem vezme ze $75 \%$, tak oni se do toho stejně nevlezou. A ted' si to představte, že máte někde byt, a já vím, že ona paní byla velice hodná, skromná, byla zvyklá žít z mála, ale ted' ještě navíc skončí ta podpora $\mathrm{v}$ nezaměstnanosti a ten pán teda pracovat nemůže. Nevím, má to tak být?“"

„Takže ted' je ta práce s tím, soustředit se na toho klienta tak, aby tu práci byl schopen sehnat a tam právě docházelo ke zjištění, že ti lidi někteří skutečně, jednak že mají zdravotní omezení, že pokud je to ta skupina těch lepších lidí, o kterých bysme řekli, že skutečně to nezneužívají ten sociální systém, takže tam je i stanovisko lékaře, že vlastně nesežene práci, protože ten lékař ho neodporučí nikde.“

$V$ připadě druhé kategorie, tzv. undeserving, naopak často dochází $k$ nastavení př́snějších hledisek posuzování, vedoucí $k$ vyšši míre kontroly těchto klientů a $k$ aplikaci nejrůznějšich prostředků disciplinace.

„Nedá se říct, že by to nějakej byl rozdíl, že bysme je házeli přes palubu. Zase se muselo vědět, jestli je to slušnej člověk, kterej má nějaký problémy se sebou a potom není schopnej s tím úřadem práce spolupracovat, anebo jestli to je vyloženě darebák, kterej má spoustu jinech zájmů, a třeba na černo pracuje, proto nešel na ten úřad práce, ted’ zneužívá dávky, alkohol atd.“

„Takže pro nás ten aktivizační plán sice byl o zaměstnání, ano, a my to tam máme, máme to tam dokladováno, kde ti klienti byli, dokonce bych řekla, že máme vysoké nároky. Klienti se nám ze začátku vymlouvali, vždyt' ty dvě tři místa za měsíc stačí. Říkáme, tři místa? Vždyt’ to stihnete za jeden den, když si je oběhnete, uděláte si takovou tu prvotní depistáž, inzerce, to přece zvládnete, máte celej měsíc volnej. Nemocnej nejste, zdravej, mladej.“

„Nebo i měla jsem tu pána, se kterým jsem sestavovala aktivizační plán, ř́kal mi, že bydlí v dřevěné boudě $\mathrm{v}$ lese. A víc př́ípadů máme, že třeba bydlí i ve staně v lese. No, bydlí... Tak jsem mu řekla, jak jsem s ním mluvila, jak řešit tu situaci, a on se odvolával na to, že byl ve výkonu trestu, že až bude mít výmaz toho trestu a že ho nikde nechtějí vzít. No a on si nedokázal trošku asi i připustit to, že trošku ta vina je i v něm, protože i tady, jak přišel na aktivizační plán, tak byl pod vlivem alkoholu.“

„Ono je to v těch lidech prostě. Kdo nikdy nedělal, dělat zase nebude, ten, kdo se snaží, může být i starší, tak..."

Individualizace př́stupu je deklarovanou alfou a omegou současných sociálních politik a v našich podmínkách hledá své naplnění v sociální práci a poradenství (ve smyslu case managementu). V důvodové zprávě $k$ zákonu o hmotné nouzi se napřiklad konstatuje: „Zákon [...] využitím sociální práce vytváři podmínky pro zabezpečení individuální práce s př́jemci pomoci v hmotné nouzi a tak zajištuje potřebné začleněni těchto osob do společnosti. "Snaha o individualizovaný př́stup $v$ poskytování pomoci je pak úzce spojena se snahou individualizovat odpovédnost 
klienta (za svou situaci a za její řešení), a to za pomoci nástrojů, jako jsou individuální akčni plány, aktivizační plány, plány individuálního motivačního postupu apod., jak se dále konstatuje v di̊vodové zprávě: ,Zákon o pomoci v hmotné nouzi propojuje poskytováni pomoci osobám s hodnocením jejich aktivity při zvyšování přímu vlastním přičiněním [...]. Přitom vycházi z principu odpovědnosti jednotlivé osoby za své sociální postaveni".

Tato snaha může být ve svých praktických důsledcích (ale samozřejmě už na koncepční rovině) plná rozporů, které nelze usmírit. Ještě předtím, než byly nové zákony sociální ochrany uvedeny do praxe a byly ve stadiu př́íprav, upozorňoval Konopásek (1998: 19) na jeden z nich: „Na úrovni obecných principů se $\mathrm{v}$ těchto materiálech (z dubna 1995) zdůrazňovalo důsledné akcentování nepeněžních forem pomoci, a to skrze ,rozvoj sociální práce, poskytování sociálních služeb a preferování poskytnutí věcné pomoci místo sociálních dávek'. To vše se vyhlašovalo jedním dechem spolu se zdůrazňováním nutnosti ,posilovat suverenitu a nezávislost klientư'. V těchto dvou direktivách je ovšem pochopitelně hluboký rozpor, který leccos prozrazuje o slabostech široširých definic sociálního zabezpečování. Zapomíná se na to, že musí-li administrátor pomoci přednostně nabízet službu před dávkou, znamená vlastně, že klient je zcela závislý na jeho posouzení a rozhodnutí. [...] Nemůže si kupovat zboží a služby dle své volby, a starat se tak sám o sebe. Je namísto toho nucen přijímat určité zboží a služby a nechávat druhé, aby se o něho starali.“"

Od administrátorek se na jednu stranu očekává, že budou u klientů podporovat (či dokonce vyžadovat) jejich vlastní aktivitu a iniciativu, že budou vyžadovat, aby klienti přijali zodpovědnost za situaci, ve které se ocitli. Současně se však administrátorky dostávaji do situací, kdy radu rozhodnutí musí činit za své klienty, kdy je tímto zbavuji subjektivity $v$ potřebách a nárocich.

„Takže my jsme měli běžně, že ti rodiče přihlásili to dítě na tuto soukromou školu, kde bylo ze začátku deset tisíc, ted' je možná dvacet tisíc, školné, a pak se divili, že jim ty peníze nechceme dát. Vůbec je nenapadlo, že když jsou na té dávce, že nemůžou dítě dát do té školy. A to bylo hodně př́padů takových, kde třeba přihlásili to dítě na školu někde, já nevím, daleko, a ted' přišli, že nemají na zaplacení tady těhletěch poplatků, internát a já nevím co, a to se hodně těžko vysvětlovalo, že až natvrdo jsme jim museli říct, podívejte se, když jste na sociálních dávkách, musíte zvážit, že to vaše dítě nemůže tak studovat."

„Já si myslím, že ti lidi, tak jak ř́íám, oni nedokáží přizpůsobit ten svůj život té svojí situaci. Takže oni bydlí v třípokojovém bytě a je vůbec nenapadne, že by mohli jít do bytu jedna plus jedna a ten třípokojový byt pustit. Protože samozřejmě ta obec by ten třípokojovej udala. Oni raději, protože nedostávají na něho celou částku, část té dávky, kterou mají na živobytí, obětují na ten byt. Ale nehnou se z něho.“ 
„A my se i snažíme docela těm lidem pomoct, prostě když si tady přijde, že potřebuje na uhlí, že nemá v zimě čím topit, tak přihlížíme i samozřjejmě k tomu, jaká je zima, jestli je vůbec zima.“

Individualizace se pak může $v$ některých př́padech zvrátit ve svưj opak a nabývat charakteru de-individualizace. Jako v uvedených citacich, kdy napríklad i posouzení toho, zda je venku dostatečná zima $k$ tomu, aby bylo nutné poskytnout klientovi pomoc, je na sociálním pracovníkovi, což vede na straně klienta ke ztrátě subjektivity a suverenity, včetně práva na soukromí.

\section{Paradox univerzality}

Pokud se hovoří o nových sociálních rizicích, zdá se, že jedna podstatná dimenze obvykle nebývá uvažována. Novým sociálním rizikem může ve svých důsledcích být, jak jsme se snažili ukázat v předcházejících oddílech, sám způsob zvládání nových sociálních rizik. Z rozhovorů s administrátorkami systému hmotné nouze je mimo jiné patrná jejich reflexe faktu, že nejen změny na trhu práce, ale i změny v systémech sociálního zabezpečení (zdravotní a sociální pojištění) vedou často k tomu, že klienti těchto systémů se ve stále větší míře stávají klienty systému hmotné nouze. ${ }^{15}$ Charakteristiky klientů systému hmotné nouze jsou stále heterogennější, jejich biografie jsou si stále více nepodobné, což klade zvýšené nároky na schopnost systému samotného tyto odlišnosti reflektovat a respektovat (někdy jsou k tomu administrátorky nabádány prŕmo metodickým pokynem). Jinými slovy, liniové pracovnice budou stále častěji narážet na problémy plynoucí z usmiřování hledisek univerzality (systému) a individualizace (biografií), které bude možné řešit jen prostřednictvím aplikace klasifikačních schémat, vyplývajících nikoli z profesionálních (což mimo jiné znamená také do jisté míry kontrolovaných), ale z doxických, tedy obecně sdílených (a začasté ne zcela korektních), představ a konstrukcí.

Krize reprezentace, jak na úrovni celého systému, tak na úrovni klasifikačních schémat, je pak primárně důsledkem toho, jak se tyto doxické představy a konstrukce stále více míjejí se sociální realitou. To jim však pranic neubírá na jejich přesvědčivosti a na síle, s jakou řídí naše jednání.

Samy liniové pracovnice očekávají, že do systému bude v budoucnosti vstupovat stále více klientů, pro které vlastně nebyl navrhován. To bude potenciálně vytvářet dva druhy tenzí. Za prvé, sám rostoucí počet klientů, v kombinaci s důrazem na individuální př́stup ze strany administrátorek, se může jevit jako stále větší problém. Za druhé, rostoucí heterogenita klientů může vést $\mathrm{k}$ situaci, kdy systémem navrhované univerzální řešení problému hmotné nouze - vlastní aktivita klientů - bude bud’to stále častěji selhávat v dosažení kýženého cíle, nebo nebude vůbec aplikovatelné.

15 Pojišt'ovací systémy bud’to nepokrývají všechny výdaje spojené s pojistnou událostí (doplatky za léky, poplatky v ambulanci, poplatky spojené s hospitalizací apod.), nebo jsou zpř́ínnována kritéria pro získání oprávnění pro čerpání z těchto systémů (např́íklad prodlužování délky doby pojištění pro získání nároku na starobní nebo invalidní důchod). 
Př́kladem skupiny, pro kterou je redefinice systému do podoby dávky za aktivitu nelogická či dokonce protismyslná, jsou starobni důchodci, kteři se ocitnou $v$ hmotné nouzi. U těchto osob selhává ochrana prostřednictvím penzijního systému, přičemž pomoc nabizená systémem hmotné nouze je neefektivní, protože má formu pobidky $k$ aktivitě spišse než kompenzace př́jmu.

„Poměrně často sem přijdou senioři, důchodci, a ptají se, jestli mají nárok na nějaké úlevy, hrazení regulačních poplatků, ale i léků. Řeknou mi, podívejte se, já mám sedm tisíc devět set důchodu, byt platím čtyři tisíce, já nevím, u doktora, kam třeba $\mathrm{v}$ důsledku své choroby chodím každý týden, tak zaplatím za poplatky a za léky třeba osm set a zůstane mi tolik a tolik. Nemůžete mi pomoct, nemůžete mi přispět? Takže já ř́́kám, že nemůžu, že jo, protože nemůžu. Myslím si, že tihle lidé se nevejdou samozřejmě do hmotné nouze, vím, že důchody byly valorizovány, budou znova valorizovány. Pokud by se to vzalo v poměru $\mathrm{k}$ cenám energií a $\mathrm{k}$ těm poplatkům $\mathrm{v}$ těch zdravotnictvích, měli by se asi ti senioři zohlednit, a zrovna tak rodiny s dětmi, že jo. Ale myslím si, že tyhlety dopady, které samozřejmě asi v globálu ekonomice republiky pomohou, jsou docela špatný, protože ty lidi nechávají dlouhodobě žít na pokraji chudoby. No a když k tomu někde přičtete, že si někde přečtete, jak se někdo má, tak to tady asi vyloženě jenom štve. Asi i jiný lidi, než jsou tihle důchodci.“"

Dalši ohroženou skupinou mohou být osoby s nizkými př́jmy, které v př́padě dlouhodobé nemoci ztrácejí schopnost zvýšit si př́jem vlastní aktivitou.

„A ted'ka to naroste určitě i těma nemocenskýma. Že budou tak ponížený, takže ty lidi nebudou vycházet, takže když budou mít nemocenské dávky, budou tady u nás. Takže dokud se jim nevrátí zase ten př́ijem z toho zaměstnání.“

Specifickou a významně ohroženou skupinou jsou také pracujicí chudí, kteři již dnes tvoři ne zcela zanedbatelnou část klientů systému hmotné nouze.

„Oni se snaží nějaké ty veřejně prospěšné práce, brigády si najít. A říkám, docela nějaká ta část těch klientů i pracuje při té dávce, protože tady jsou tak nízké platy, že někdy opravdu se stane, že pokud mají víc dětí, že se přesto, že pracují, do té dávky vlezou. Takže to je hrozně smutné a ty prřijmy tady jsou tak hrozně nízké, že tady běžně se prŕijem pohybuje od těch osmi do deseti tisíc, v těch dělnických, čistého.“

Systém hmotné nouze, jako systém poslední záchrany pro ty, kteří se dostanou z nejrůznějších důvodů do tísnivé situace, by jim měl pomoci vymanit se z takto obtížné a stigmatizující situace. Je však otázkou, zda je toho tento systém schopen dnes, a zda toho bude schopen v budoucnosti, pokud se bude dále heterogenizovat jeho klientela a př́padně se navíc budou zpř́śňovat pravidla poskytování pomoci. Již dnes jsme v rámci administrace systému hmotné 
nouze konfrontováni s jevem, který bychom mohli označit jako paradox univerzality: dilemata spojená s přiznáváním nároku na dávku jsou stále častěji důsledkem zužování kritérií oprávněnosti, přičemž právě toto zužování kritérií bylo vedeno primárně snahou proces rozhodování zjednodušit.

Univerzální řešení v podobě administrativní rekomodifikace, $v$ kombinaci se schumpeteriánským obratem v ekonomice, který Offe v polovině osmdesátých let, kdy s termínem administrativní rekomodifikace přišel, zřejmě nepředpokládal, se může změnit ve skutečnou noční můru v okamžiku, kdy povede ke snižování standardů na trhu práce (co se týče pracovních podmínek i remunerace) nejen pro ty, kteří budou administrativně rekomodifikováni, ale i pro významnou část těch, kteří zaměstnání mít budou.

\section{Závěr}

Velká část problémů a dilemat, produkovaných kapitalismem fordistického typu a s ním spojeným typem sociálního státu, se kterými se liniové pracovnice setkávaly a dosud setkávají, neproblematizuje aktuální konstrukci sociální reality, jejíž arbitrárnost je naturalizována mimo jiné i prostřednictvím sociálního zákonodárství, které kupř́kladu reglementuje rozdíl mezi chudým a potřebným (oprávněným) chudým. Tento typ problémů a dilemat, vyplývajících z aplikace obecných pravidel na konkrétní prípady, tedy z usmiřování hledisek univerzality a individualizace; $\mathrm{z}$ rutinizace a formalizace předepsaných postupů jednání, tedy z vyrovnávání tlaku množství klientů na kapacitu pracovníků; z jisté stereotypizace, tedy z kategorizace klientů, která může mít často opresivní až diskriminační charakter, neútočí na jejich smysl pro realitu, na korespondenci mezi sociálními a mentálními strukturami, jinými slovy, na jejich doxickou zkušenost, která tvoří základ schémat percepce a klasifikace. Existují však změny ve způsobech produkce (post-fordismus), biologické (demografický přechod) i sociální (depolitizace) reprodukce, které mohou být zdrojem nových problémů a dilemat, potenciálně otevírajících trhliny v naturalizované konstrukci reality a zpochybňující stávající doxickou zkušenost.

Zmíněné změny ve způsobech produkce i reprodukce nově definují také vzájemné vztahy kolektivních i individuálních aktérů. Ekonomický systém vnáší tržní principy i do oblastí, které se ř́́dily jinými principy. Welfare state, vázaný na keynesiánský ekonomický model a založený na horizontálních formách solidarity a pojištění, nahrazuje workfare state, založený na transferu zodpovědnosti na individuální úroveň, a to $\mathrm{v}$ rostoucím počtu situací (nemoc, stárí, nezaměstnanost atd.). Univerzální řešení sociálních rizik vidí workfare state v pracovní aktivitě (která se stává, vedle majetkové situace, druhým univerzálním kritériem přiznání nároku) a př́padných vertikálních transferech. Aktuální změny na pracovním trhu, zejména jeho flexibilizace, kdy se nositeli zvýšeného rizika stávají kategorie zaměstnanců, které byly v nedávné minulosti vcelku spolehlivě chráněny a se kterými se v systémech bazální sociální ochrany (obdobných našemu systému hmotné nouze) prríliš nepočítalo, však zároveň způsobují nárůst heterogenity př́ijemců sociální pomoci a větší tlak na tento systém.

Paralelní trend redukce počtu kritérií pro určování oprávněnosti a jejich aplikace na všechny žadatele pak v praxi vede $\mathrm{k}$ jistému rozporu: čím heterogennějš́ je skupina, která se může ocitnout v situaci hmotné nouze (často v důsledku projevu nových sociálních rizik), 
tím homogennější podmínky, tedy užší kategorie, jsou pro přiznání určitého typu pomoci nastaveny. Ve větší míře tak vznikají pochybnosti ohledně oprávněnosti nároků či jejich výše.

$\mathrm{V}$ př́padě nových problémů a dilemat, zhmotněných v pojmu nová sociální rizika, nemohou být aplikována hlediska nároku vyplývající čistě ze zákona právě proto, že tento typ problémů není v zákoně explicitně řešen, a musí být aplikována hlediska jiná. Hlediska vyplývající z doxické zkušenosti, hlediska morální a hodnotová, která tvoří nezpochybnitelný a nezpochybňovaný základ konstrukce sociální reality. Právě stávající doxická zkušenost liniových pracovnic i klientů je však novými problémy a vzájemně se vylučujícími kritérii podkopávána. Důsledkem tohoto procesu ne/řešení obtížných situací, v nichž se klienti systému hmotné nouze ocitají, je ztráta důvěry v tento systém nejen na straně klientů (a to i těch potenciálních), ale i na straně samotných administrátorek, liniových pracovnic tohoto systému.

Kritickým se v tomto ohledu stává takový typ problémů, jejichž charakter překračuje hranice pomoci v hmotné nouzi, jak ji definuje zákon. Zde klienti i liniové pracovnice vstupují do prostoru, ve kterém bud'to žádná pomoc poskytnuta být nemůže, nebo je její poskytnutí závislé na kreativním přístupu liniových pracovnic. Jejich kreativní prrístup do značné míry závisí na (morálním) posouzení oprávněnosti či neoprávněnosti nároku daného klienta.

Byrokratický systém administrující sociální pomoc, a pohybující se v omezeních daných jeho vlastním fungováním, je nucen se vyrovnat s rostoucí heterogenitou žadatelů o pomoc. V této situaci musí současně naplňovat, jak tvrdí např́íklad Konopásek (1998), požadavek na univerzalitu poskytované pomoci (jako základního legitimizačního předpokladu tohoto systému), i požadavek na individualizaci posouzení nároků, vyrůstající z rostoucí heterogenity žadatelů. Důsledkem této komplikované operace, která probíhá simultánně na úrovni systému (zákonodárství) i na úrovni komunikace s klientem, je prohlubující se krize reprezentace a z ní vyplývající obtíže. Nová sociální rizika, produkt změny ve způsobech produkce i reprodukce, otevírají uvnitř systému sociální ochrany interpretační prostor, pro který však zákonodárství neposkytuje adekvátní oporu. Uvědomují si to jak administrátorky, tak jejich klienti, což ohrožuje efektivitu i legitimitu celého systému.

\section{Literatura}

BOLTANSKI, Luc ; CHIAPELLO, Eve. The New Spirit of Capitalism. London : Verso, 2007. 601 s. ISBN 1-84467-165-6.

BONOLI, Guiliano. Time Matters. Postindustrialization, New Social Risks, and Welfare State Adaptation in Advanced Industrial Democracies. Comparative Political Studies, 2007, roč. 40, č. 5, s. 495 - 520. ISSN 0010-4140.

BOURDIEU, Pierre. Outline of a Theory of Practice. Cambridge : Cambridge University Press, 1977. 244 s. ISBN 0-52129-164-4.

BOURDIEU, Pierre. Acts of Resistance. Against the Tyranny of the Market. New York: The New Press, 1998a. 128 s. ISBN 1-56584-523-7.

BOURDIEU, Pierre. Teorie jednání. 1. vyd. Praha : Karolinum, 1998b. 179 s. ISBN 80-718-4518-3.

BOURDIEU, Pierre. Firing Back. Against the Tyranny of the Market 2. New York: The New Press, 2003. 83 s. ISBN 1-85984-658-0.

BOURDIEU, Pierre. The Social Structures of the Economy. Cambridge : Polity Press, 2005. $180 \mathrm{~s}$. ISBN 0-74562-539-3. 
BOURDIEU, Pierre ; Wacquant Loïc J. D. An Invitation to Reflexive Sociology. 1. vyd. Chicago : University of Chicago Press, 1992. 348 s. ISBN 0-22606-741-4.

BOURDIEU, Pierre [et al.]. The Weight of the World. Social Suffering in Contemporary Society. 1. vyd. Stanford : Stanford University Press, 1999. 656 s. ISBN 0-80473-844-6.

CERAMI, A. New Social Risks in Central and Eastern Europe : The Need for a New Empowering Politics of the Welfare State. Sociologický časopis, 2008, roč. 44, č. 6, s. 1089 - 1110. ISSN 0038-0288.

ESPING-ANDERSEN, Gosta. The Three Worlds of Welfare Capitalism. Princeton : Princeton University Press, 1990. 260 s. ISBN 0-69102-857-6.

HOLDEN, Chris. Decommodification and the Workfare State. Political Studies Review, 2003, roč. 1, č. 3, s. 303 - 316. ISSN 1478-9299.

HORÁK, Pavel ; HORÁKOVÁ, Markéta. Role liniových pracovníků ve veřejné politice. Sociologický časopis, 2009, roč. 45, č. 2, s. 369 - 395. ISSN 0038-0288.

JAHODA, Robert ; KOFROŇ, Pavel ; ŠIMÍKOVÁ, Ivana. Změny v oblasti pomoci v hmotné nouzi a jejich dopady (př́jemci a dávky, aplikace nových institutů). 1. vyd. Praha : Výzkumný ústav práce a sociálních věcí, v.v.i., 2008. 106s. ISBN 978-80-741-6029-5.

JANEBOVÁ, Radka ; ČERNÁ, Lucie. Konstrukce žen-klientek a mužů-klientů v praxi sociální práce. Gender, rovné príležitosti, výzkum, 2008, roč. 8, č. 2, s. 37 - 45. ISSN 1213-0028.

JESSOP, Bob. The Transition to Post-Fordism and the Schumpeterian Workfare State. In BURROWS, R., LOADER, B. (eds.) Towards a Post-Fordist State? London : Routledge. 1996, s. 13 - 37. ISBN 0-41509-967-6.

JESSOP, Bob. The Changing Governance of Welfare : Recent Trends in its Primary Functions, Scale, and Modes of Coordination. In MANNING, N., SHAW, I. (eds.) New Risks, New Welfare : Signposts for Social Policy. Oxford: Blackwell Publishers, 2000, s. 12 - 23. ISBN 0-63122-042-9.

JESSOP, Bob. The Future of the Capitalist State. Cambridge : Polity Press, 2002. 303 s. ISBN 0-74562-273-9.

KONOPÁSEK, Zdeněk. Estetika sociálního státu. O krizi reprezentace (nejen) v sociálním zabezpečení. 1. vyd. Praha: GplusG, 1998. 341 s. ISBN 80-861-0314-5.

LEONARD, Peter. Postmodern Welfare. Reconstructing an Emancipatory Project. London : SAGE, 1997. 187 s. ISBN 0-80397-610-0.

MANNING, Nick ; SHAW, Ian. (eds.) New Risks, New Welfare : Signpost for Social Policy. Oxford : Blackwell, 2000. 158 s. ISBN 0-63122-042-9.

McDONALD, Catherine ; MARSTON, Greg. Workfare as Welfare : Governing Unemployment in the Advanced Liberal State. Critical Social Policy, 2005, roč. 25, č. 3, s. $374-401$. ISSN 0261-0183.

MENNERICK, Lewis A. Client Typologies : A Method of Coping With Conflict in the Service Worker-Client Relationship. Work and Occupations, 1974, roč. 1, č. 4, s. 396 - 418. ISSN 0730-8884.

OFFE, Claus. Contradictions of the Welfare State. London : Hutchinson, 1984. 304 s. ISBN 0-26265-014-4.

OULTON, Nicholas. Must the Growth Rate Decline? Baumol's Unbalanced Growth Revisited. Oxford Economic Papers, 2001, roč. 53, č. 4, s. 605 - 627. ISSN 0030-7653.

PIERSON, Paul. (ed.) The New Politics of the Welfare State. Oxford : Oxford University Press, 2001. 528 s. ISBN 0-19829-756-7.

ROSENTHAL, Patrice ; PECCEI, Riccardo. The Social Construction of Clients by Service Agents in Reformed Welfare Administration. Human Relations, 2006, roč. 59, č. 12, s. 1633 - 1658. ISSN 1741-282X.

ROSENTHAL, Patrice ; PECCEI, Riccardo. The Work You Want, The Help You Need : Constructing the Customer in Jobcentre Plus. Organization, 2007, roč. 14, č. 2, s. 201 - 223. ISSN 1461-7323. 
SARACENO, Chiara. Deconstructing the Myth of Welfare Dependence. In SARACENO, C. (ed.) Social Assistance Dynamics in Europe. National and Local Poverty Regimes. 1. vyd. Bristol : The Policy Press, 2002, s. 235 - 258. ISBN 1-86134-314-0.

TAYLOR-GOOBY, Peter. New Risks and Social Change. In TAYLOR-GOOBY, P. (ed.) New Risks, New Welfare. The Transformation of the European Welafare State. Oxford : Oxford University Press, 2004a, s. 1 -28. ISBN 0-19926-727-8.

TAYLOR-GOOBY, Peter. New Social Risks in Postindustrial Society : Some Evidence on Responses to Active Labour Market Policies from Eurobarometer. International Social Security Review, 2004b, roč. 57, č. 3, s. $45-64$. ISSN 0020-871X.

TAYLOR-GOOBY, Peter. (ed.) New Risks, New Welfare. The Transformation of the European Welafare State. Oxford : Oxford University Press, 2004c. 239 s. ISBN 0-19926-727-8.

WACQUANT, Loïc J. D. The Penalization of Poverty and the Rise of Neo-Liberalism. Capitulo Criminológico, 2003a, roč. 31, č. 1, s. 7 -22. ISSN 0798-9598.

WACQUANT, Loïc J. D. Toward a Dictatorship Over the Poor? Notes on the Penalization of Poverty in Brazil. Punishment \& Society, 2003b, roč. 5, č. 2, s. 197 - 205. ISSN 1741-3095.

WACQUANT, Loïc J. D. Urban Outcast. A Comparative Sociology of Advanced Marginality. Cambridge : Polity Press, 2008. 360 s. ISBN 0-74563-125-7.

\section{Autoři}

Ivana Šimíková vystudovala sociologii a sociální politiku a sociální práci na Fakultě sociálních studií Masarykovy a je zaměstnána ve Výzkumném ústavu práce a sociálních věcí v Brně, kde se podílí na výzkumech a studiích zaměřených na systém sociální ochrany, téma chudoby a sociálního vyloučení etnických menšin a evaluaci sociálních programů.

Kontakt: ivana.simikova@vupsv.cz

Jiří Vyhlídal vystudoval sociologii, sociální politiku a sociální práci na Fakultě sociálních studií Masarykovy a kvantitativní metody analýzy sociální politiky na Katolické univerzitě v Lovani. Pracuje jako výzkumný pracovník Výzkumného ústavu práce a sociálních věcí v Brně, kde se věnuje především otázkám trhu práce a pracovní migrace.

Kontakt: jiri.vyhlidal@vupsv.cz 